\title{
Aspartate aminotransferase-platelet ratio index, adiponectin and body mass index in children with fatty liver
}

\author{
Ninung RD Kusumawati ${ }^{*}$ Maria Mexitalia, Suci Romadhona, Agustini Utari \\ From 7th APPES Biennial Scientific Meeting \\ Nusa Dua, Bali. 14-17 November 2012
}

Obesity in children is becoming a global epidemic. Nonalcoholic fatty liver disease (NAFLD) is a highly prevalent and potentially serious complication of childhood obesity. Adiponectin level was decreased on obese children. Adiponectin is a protective factor against non-alcoholic fatty liver disease on obesity. The early identification of fibrosis is important in children with NAFLD in order to prevent the development of liver disease in adulthood. One of non-invasive procedure to predict liver fibrosis is the aspartate aminotransferase (AST)-platelet ratio index (APRI). The purpose of our study was to assess a correlation between APRI, adiponectin and body mass index (BMI) in obese children with fatty liver.

A cross-sectional study was conducted from August to September 2007. Subjects were obese children from one junior high school in Semarang, Indonesia. Complete blood count, transaminase enzyme measurement, adiponectin level and abdominal ultrasound (USG) were performed on each subject. Only subjects with bright liver on USG underwent APRI analysis. Spearman's correlation was used for statistical analysis.

Of 37 obese children, 19 children had bright liver on USG. The mean APRI was 0.16 (0.119). The mean Adiponectin was 4.04. Only one obese subject (5.0\%) with bright liver had an APRI $>0.5$. APRI was significantly correlated to alanine amino transferase (ALT) levels $(r=0.62)$, but not significantly correlated to BMI $(r=0.35)$ and adiponectin $(r=0.45)$. There was no correlation between BMI, ALT $(r=0.16)$, AST $(r=0.16)$, and adiponectin $(r=$ 0.30 ).

This study suggest that obese children with fatty liver might have high APRI levels indicating the presence of

Department of Pediatric, Faculty of Medicine, Diponegoro University / Dr. Kariadi Hospital, Semarang, Indonesia

\section{O) BioMed Central}

(c) 2013 Kusumawati et al; licensee BioMed Central Ltd. This is an Open Access article distributed under the terms of the Creative Commons Attribution License (http://creativecommons.org/licenses/by/2.0), which permits unrestricted use, distribution, and reproduction in any medium, provided the original work is properly cited. liver fibrosis. However, there is no correlation between APRI, adiponectin and BMI.

Published: 3 October 2013

doi:10.1186/1687-9856-2013-S1-P107

Cite this article as: Kusumawati et al:: Aspartate aminotransferaseplatelet ratio index, adiponectin and body mass index in children with fatty liver. International Journal of Pediatric Endocrinology 20132013 (Suppl 1):P107.

Submit your next manuscript to BioMed Central and take full advantage of:

- Convenient online submission

- Thorough peer review

- No space constraints or color figure charges

- Immediate publication on acceptance

- Inclusion in PubMed, CAS, Scopus and Google Scholar

- Research which is freely available for redistribution 